\title{
抵抗挿入による電力回生ブレーキの高速域電気ブレーキカ増大
}

\author{
正員 山下 道寛 正員 小笠 正道 正員 渡邊 朝紀
}

((財) 鉄道総合技術研究所)

\section{Electric Brake Force Increase of Regenerative Brake in the High-Speed Range by Inserted Rheostats}

\author{
Michihiro Yamashita, Member Masamichi Ogasa, Member Tomoki Watanabe, Member
}

(Railway Technical Research Institute)

Electric railway vehicles have come to use regenerative brake for normal operation from the top speed to almost zero speed. In the regenerative brake, the terminal voltage of traction motor cannot be increased due to the limited catenary voltage and blocking voltage of semiconductor devices. Therefore, the electrical brake force in the high-speed is smaller than that for middle or low speed. The total brake force for high-speed range mainly depends on the mechanical brake.

By inserting resisters between the inverter and traction motor, the regenerative brake force can be increased in the high-speed range without increase of the rated power or current of inverter.

In light-density line sections, regenerative brake force is frequently inactivated under light-load condition. In this condition, rheostats consume part of regenerative power generated by traction motors when the electric vehicle is braking. Then, the peak regenerative power for the feeder line will be decreased and electrical brake is easily activated, which is another merit.

We studied the possibility to increase the regenerative brake force in the high-speed range by considering characteristic curves, RMS current, and regeneration rates.

キーワート：電気車, 電気ブレーキ, 発電抵抗器, 回生ブレーキ, 発電ブレーキ

\section{1.はじめに}

最近, 誘導電動機を主電動機とする電気鉄道車両に ベクトル制御が応用され始め，軽負荷時の負荷に見合 った回生ブレーキ制御や空転・滑走制御等に優れた効 果が現れている。

一方, 現在の電気鉄道車両では, 低速域において電 気ブレーキが絞られ，不足分を機械ブレーキにて禣う ことで完全停止させている。これは, 停止まで電気ブ レーキを掛けることができないとされていたためであ る。そのため，電気ブレ一キから機械ブレーキへの切 り替え (電空切替) に伴うショックが乘り心地に影響 を与えたり，駅構内での停止閒際においてキ一音が生 じる場合があった。しかし，原理的には電気ブレーキ のみで車両を零速まで停止させることが可能なはずで ある。そして、この件に関しては最近検討が進み, 試 験結果や実例が報告されている。(1),(2),(3),(4)

鉄道車両用の主電動機は，一般に定トルク域（一定 磁束域) の終端が最高速度の1/2 1/3 と低く設計され ている。通常, 中高速域では弱め磁束制御, 特性加速
を行うため, 主電動機トルクは低下する。そのため, 高速域における電気ブレーキ力はあまり期待できず, ブレーキカの多くを機械ブレーキに頼っている場合が 多い。誘導電動機の特性領域において, 電気プレーキ 力を增大させる試みはまだない。パワーの大きい高速 域において電気ブレーキ力を增大させることができれ ば, ブレーキシューやライニングの摩耗による交換や 検査などのメンテナンスを低減させることが可能であ る。

直流電動機のチョッパ制御では, 高速域の電気ブレ 一キ力增大に関して, 次のような抵抗挿入事例がある。 旧国鉄の 2001 系通勤電車（直流直巻電動機駆動）に おいて, 通常の回生ブレーキ方式では高速域における 電気ブレーキ力が期待できないため，速度 $75[\mathrm{~km} / \mathrm{h}]$ 以 上では, 発電抵抗を電機子チョッパと直流電動機間に 直列に挿入することで, ブレーキ力（主電動機トルク） を增大させている。図1に201系通勤電車の主回路 の概略図を示す。実際には直流直巻電動機は 4 直列 2 並列（8台）接続されている。簡単のため図1では電 動機 1 台のみで表している。ここで, Lf: フィルタリア 
クトル, C:フィルタコンデンサ, $\mathrm{Re}$ :発電抵抗, MSL: 主平滑リアクトル，G:歯車装置である。

本論文では, インバー夕制御車に対し，機械ブレ一 キの負担が最も大きくなる高速域において，インバー 夕と主電動機（誘導電動機）間に発電抵抗を挿入する ことを提案し，電気ブレーキ力を增大させることを検 討した。

回生ブレーキ時の主電動機端子電圧の上限は, 主に 架線電压によって制限されていて，高速域では一定電 圧となる。そのため, 弱め磁束領域や特性領域では, 電気ブレーキ力が定トルク域に比べ小さい。そこで, 発電抵抗を挿入することにより，抵抗の電圧降下分だ け主電動機の端子電圧を上昇させることで, インバー 夕交流出力端子電圧の值を変えずに, 停動トルクを增 大させることができる。その結果, インバータの容量 を增加させることなく，高速域の電気ブレーキ力増大 が可能となる。また，インバータ容量增大と主電動機 定格速度向上によって電気ブレーキ力を增大させた場 合に較べて，本方式では主電動機発電電力の一部が発 電抵抗により消費されるため，高速域に拈ける架線へ の回生電力ピークが抑制され，軽負荷となりやすい線 区に対して，回生失効抑制に効果があると考えられる。 なお，検討のモデルには，通常の近郊電車を用いて いる。

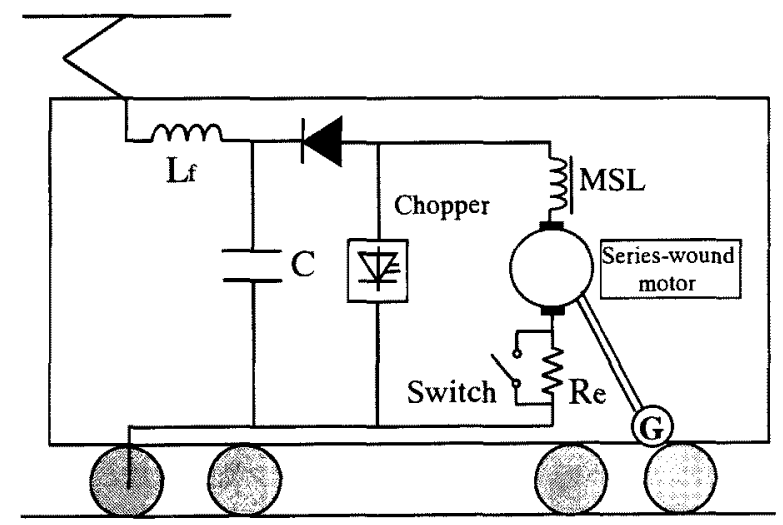

図1チョッパ駆動電車の主回路システムの概要

Fig. 1 Schematic diagram of chopper-driven traction circuit system.

\section{2. 主電動機特性の算出}

本論文で検討する主回路システムの概略を図 2 に 示す。誘導電動機で駆動される電車に対し，インバー 夕と主電動機間に, 発電抵抗 $R$ と発電抵抗短絡用のス イッチを挿入している。力行時にはスイッチが閉じて 抵抗 $R$ を短絡する。

高速域の回生時にはスイッチを開きインバータと主 電動機間に発電抵抗が挿入された状熊となる。抵抗挿入 により, 発電抵抗が受け持つ電圧分だけ主電動機端子電
圧を従来の主電動機端子電圧より上昇させることが可 能となる。その結果, 高速域における主電動機の停動卜 ルクが増大し, インバータの電流容量を増加させること なく, 高速域の電気ブレーキ力增大が可能となる。

現在のところ,スイッチには機械的な真空遮断器か 半導体素子を組み合わせた電子スイッチを想定してい る。

通常動作では,力行中はスイッチが投入されていて ブレーキ動作を始めるときにスイッチが開放され，抵 抗が捕入された状態となる。そして, 高速域から減速 し, 主電動機端子電圧が低下し発電抵抗が不要になっ た時点で, 発電抵抗による回生電力の損失を抑えるた め,スイッチを閉じ抵抗を短絡させる。

主電動機が通電されているときのスイッチ動作は, 投入動作であるため, 動作時の過電圧やアークといっ た問題は少ないと考える。

抵抗 $R$ の值は $1,2,3[\Omega] の 3$ 通りの場合を検討 した。

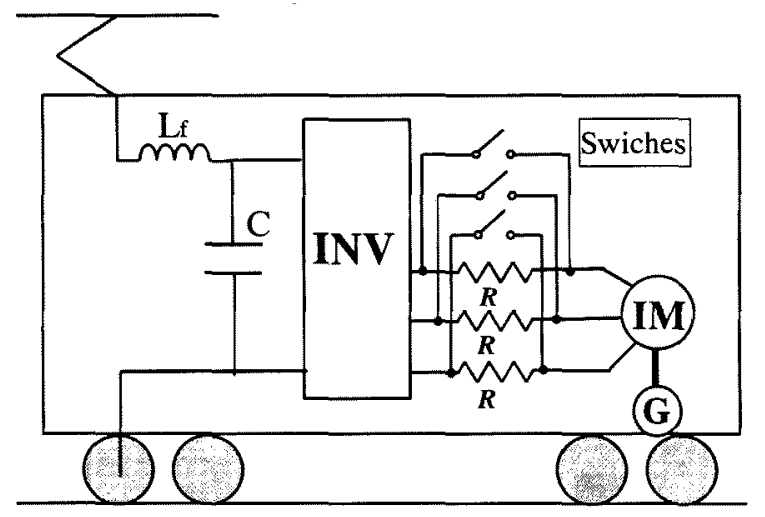

図2 インバータ駆動電車の主回路システムの概要 Fig. 2 Schematic diagram of inverter-driven traction circuit system. (rheostats insertion type)

電源電圧と同期して回転する $d-q$ 座標上において， 瞬時ベクトルで記述される誘導電動機の定常状態にお

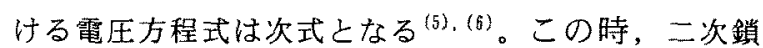
交磁束ベクトルは $d$ 軸に一致しているものとする。簡 単化のため, 架線とインバー夕間の $L C$ フィルタの動 特性については考虑していない。

$$
\begin{array}{ll}
v_{1 d}=R i_{1 d}-\omega \sigma L_{1} i_{1 q} & {[\mathrm{~V}]} \\
v_{1 q}=R i_{1 q}+\omega L_{1} i_{1 d} & {[\mathrm{~V}]} \\
\tau=P \frac{M^{2}}{L_{2}} i_{1 d} i_{1 q} & {[\mathrm{~N}-\mathrm{m}]} \\
\omega=\omega_{2 n}+\omega_{s} & {[\mathrm{rad} / \mathrm{s}]} \\
\omega_{s}=\frac{R_{2}}{L_{2}} \cdot \frac{i_{1 q}}{i_{1 d}} & {[\mathrm{rad} / \mathrm{s}]}
\end{array}
$$

ここで,

$i_{1 d}, i_{1 q}$ :一次側の $d-q$ 軸電流, $i_{2 d}, i_{2 q}$ :二次側の $d-q$ 
軸電流 $v_{1 d}, v_{1 q}$ :一次側の $d-q$ 軸電圧, $v_{2 d}, v_{2 q}$ : 二次側 の $d-q$ 軸電圧, $\phi 1 d, \phi 1 q::$ 一次側の $d-q$ 軸磁束, $\phi 2 d, \phi 2 q$ : 二次側の $d-q$ 軸磁束, $\tau$ : トルク, $\omega$ :一次角周波数, $\omega_{2 \mathrm{n}}$ : 回転子角周波数, $\omega_{s}$ : すべり角周波数, $R_{1}$ : 一次 抵抗 $R_{2}$ : 二次抵抗 $L_{1}$ :一次インダクタンス, $L_{2}$ : 二次インダクタンス, $M$ : 相互インダクタンス, $\sigma=1-\mathrm{M}^{2} / \mathrm{L}_{1} \mathrm{~L}_{2}$ ：もれ係数, $P$ :極対数

主電動機トルクてとブレーキ力 $F$ の関係と, 回転角 速度 $\omega_{2 \mathrm{n}}$ と車両速度 $V_{t}$ の関係を(6),(7)式に示す。

$$
\begin{array}{rlrl}
F & =\frac{G r}{r} \tau & {[\mathrm{N}]} \\
V t & =\frac{3.6 r \omega_{2 n}}{P G_{r}} & {[\mathrm{~km} / \mathrm{h}]} \\
\text { ここで, } r: \text { 車輪半径, } G_{r}: \text { 歯車比 } ~ & \text { とする。 }
\end{array}
$$

(1),(2)式のパラメータは, 図 3 で表される誘導電動機 の等価回路パラメータと等価である。ここで， $R$ は発 電抵抗值を表し, 誘導電動機等価回路に含めて表現し ている。

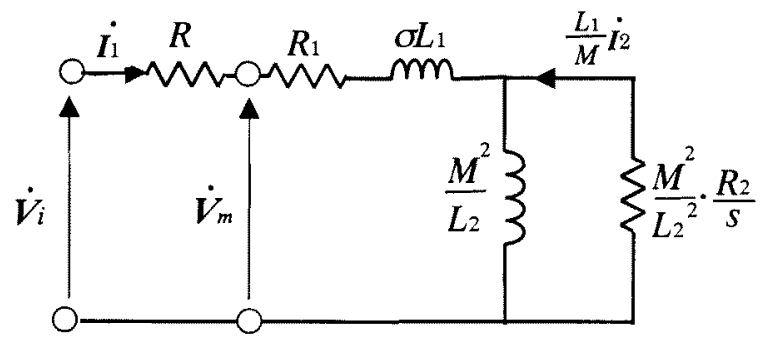

図 3 誘導電動機等価回路

Fig.3 Equivalent circuit of induction motor

表 1 主電動機の定数

Table.1 Parameters of traction motor

\begin{tabular}{|ll|c|}
\hline 一次抵抗 & $R 1[\Omega]$ & 0.0942 \\
\hline 三次抵抗 & $R 2[\Omega]$ & 0.0886 \\
\hline 一次インダクタンス & $L_{1}[\mathrm{H}]$ & 0.034 \\
\hline 二次インダクタンス & $L 2[\mathrm{H}]$ & 0.034 \\
\hline 相互インダクタンス & $M[\mathrm{H}]$ & 0.033 \\
\hline 極数 & $P$ & 4 \\
\hline 定格電圧 & {$[\mathrm{V}]$} & 1100 \\
\hline 定格電流 & {$[\mathrm{A}]$} & 125 \\
\hline 定格周波数 & {$[\mathrm{Hz}]$} & 100 \\
\hline
\end{tabular}

ここで, $V_{1}:$ 一次電圧フエーザ, $\dot{I}_{1}$ : 一次電流フ エーザ, Iz: 二次電流フェーザである。

$$
\begin{aligned}
& I_{m}=\left|\dot{I}_{1}\right|=\sqrt{i_{1 d}^{2}+i_{1 q}^{2}} / \sqrt{3} \\
& V_{m}=\left|\dot{V}_{1}\right|=\sqrt{v_{1 d}^{2}+v_{1 q}^{2}}
\end{aligned}
$$

$I_{m}:$ 主電動機電流実効值 $V_{m}:$ 主電動機線間電圧実効值 $V_{i}:$ インバータ出力端子電圧実効值

(1),(2)式に $R$ を加えて算出した $v_{1 \mathrm{~d}}, v_{1 \mathrm{q}}$ を用いて (9) 式で $V_{i}$ 式を算出。
$F:$ 各軸ブレ一キカ（ブレーキ時は負の値とする）

表1に主電動機の定数を示す。

発電抵抗值に対する停動トルクの值は, 次式(5)で表 され，発電抵抗值 $R$ に対する停動トルクてbの特性が 把握できる。

$$
\begin{aligned}
\tau_{b d}= & \frac{N_{p} R_{2} M^{2}|V|^{2} \omega_{s}}{\left(R_{s} R_{2}-\omega L_{1} \omega_{s} L_{2} \sigma\right)^{2}+\left(R_{s} \omega_{s} L_{2}+R_{2} \omega L_{1}\right)^{2}} \\
= & -\frac{N_{p} M^{2}\left|V_{1}\right|^{2}}{2 L_{2}} \\
& \times \frac{1}{\sqrt{R_{s}{ }^{2}+\left(\omega L_{1}\right)^{2}} \sqrt{R_{s}^{2}+\left(\omega L_{1} \sigma\right)^{2}}-R_{s} \omega L_{1}(1-\sigma)} \\
= & -\frac{\left.N_{p}(1-\sigma)|V|\right|^{2}}{2 L_{1} \sigma \omega^{2}} \quad[\mathrm{~N}-\mathrm{m}](10) \\
& \times \frac{1}{\sqrt{1+\left(\frac{R_{s}}{\omega L_{1}}\right)^{2}} \sqrt{1+\left(\frac{R_{s}}{\omega L_{1} \sigma}\right)^{2}}-\frac{R_{s}(1-\sigma)}{\omega L_{1} \sigma}} \\
& こ こ て ゙, \quad R s=R_{1}+R, \quad \sigma=1-\frac{M^{2}}{L L_{2}}
\end{aligned}
$$

さらに，二次入力 $\mathrm{P}_{2 \mathrm{bd}}$ との関係は以下のように表さ れる。ここで, $\tau_{1}=L_{1} / R \mathrm{~s}$ とする。

$$
\begin{aligned}
P_{2 b c}=\omega \tau_{b d}= & -\frac{N_{p}\left(1-\sigma|V|^{2}\right.}{2 L_{1} \sigma} \\
& \times \frac{\tau_{1}}{\sqrt{1+\left(\omega \tau_{1}\right)^{2}} \sqrt{1+\left(\frac{\omega \tau_{1}}{\sigma}\right)^{2}}-\frac{(1-\sigma)}{\sigma}}[\mathrm{W}](11)
\end{aligned}
$$

\section{3. 回生ブレーキ性能曲線}

$<3 ， 1>$ 現行の回生性能曲線従来の典型的な電 気ブレーキ特性について, 図 5 を用いて説明する。簡 単のために通常使用される最大ブレーキ時の回生ブレ 一キ性能曲線とする。性能曲線上の各諸量は, (1) (10) 式の関係から導出した。図 4〜9に示す添字の0は, 現行の回生ブレーキ性能曲線における各值を表す。以 下では, インバータの半導体素子の電流容量と架線電 圧の制限より $I_{m}=222[\mathrm{~A}], V_{i}=1300[\mathrm{~V}]$ を上限值として発 電抵抗を挿入したときの回生性能曲線について検討し た。なお, 歯車伝達効率は 0.95 とし, インバー夕効率 は無視した。

図 4 において, 最高速度 $130[\mathrm{~km} / \mathrm{h}]$ (このとき $F_{0}=-$ $764[10 \times \mathrm{N}] ）$ から速度 $80[\mathrm{~km} / \mathrm{h}]$ までは, 端子電圧 $V_{m}$ とすべり角周波数 $\omega_{s}$ 一定としている。列車速度の低 下 $\left(\omega_{2 n}\right.$ の減少) につれて電気ブレ一キ力 $F_{0}$ は, 回転 子角周波数 $\omega_{2 \mathrm{n}}$ の逆数の 2 乗 $1 / \omega_{2 \mathrm{n}}{ }^{2}$ に比例し, 速度 $80[\mathrm{~km} / \mathrm{h}]$ で定トルク領域(このとき $\left.F_{0}=-2136[10 \times \mathrm{N}]\right)$ に 達する。この領域 $(130 \rightarrow 80[\mathrm{~km} / \mathrm{h}])$ は特性領域である。

さらに速度が低下すると, 端子電圧 $V_{m}$ が一定です ベり角周波数 $\omega_{\mathrm{s}}$ が回転子角周波数 $\omega_{2 \mathrm{n}}$ に比例して減少 する。この時, 磁束は一次角周波数 $\omega_{1}$ に逆比例し, 徐々 


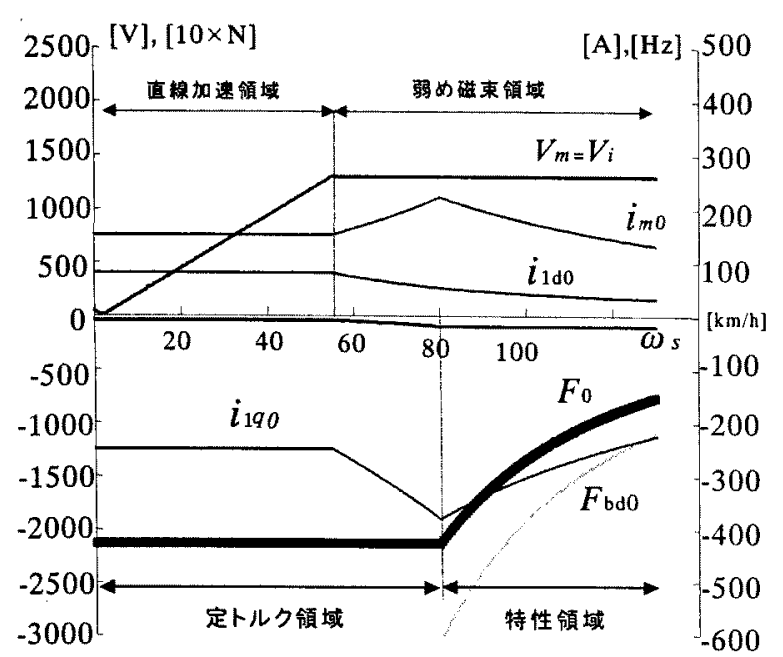

図 4 回生ブレーキ性能曲線（現行）

Fig. 4 Conventional characteristic curves

of regenerative brake. (conventional)

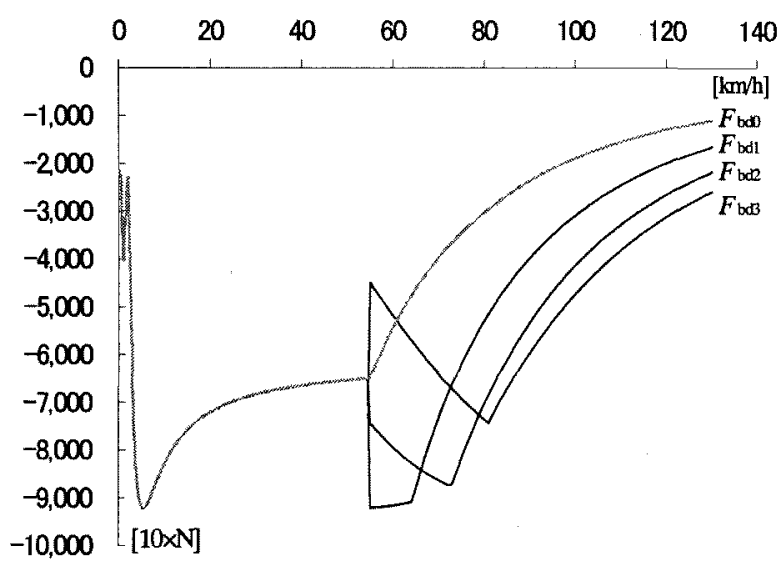

図 6 抵抗挿入時における停動トルク特性

Fig.6 Characteristic curves of break down torque with resistor.

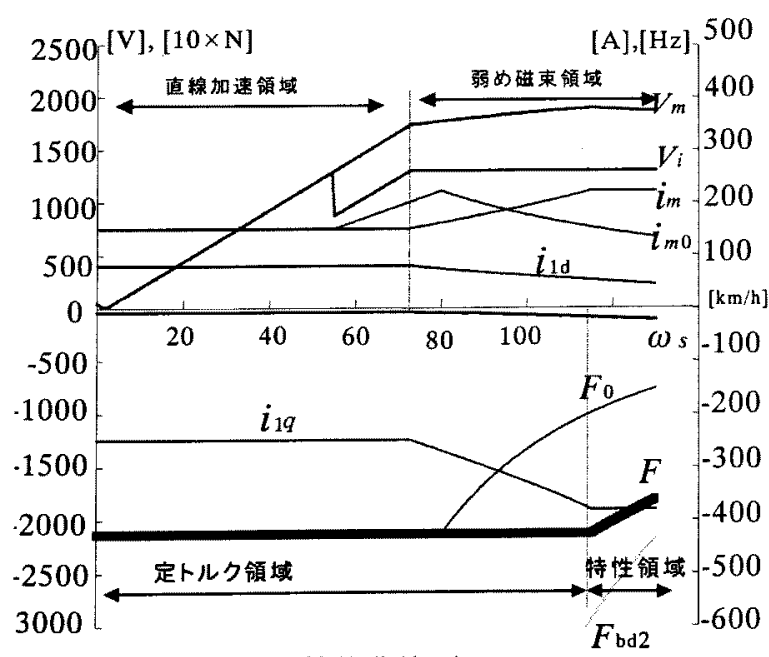

図 8 回生ブレーキ性能曲楾 $(R=2[\Omega])$

Fig. 8 Characteristic curves of regenerating brake.

$(R=2[\Omega])$

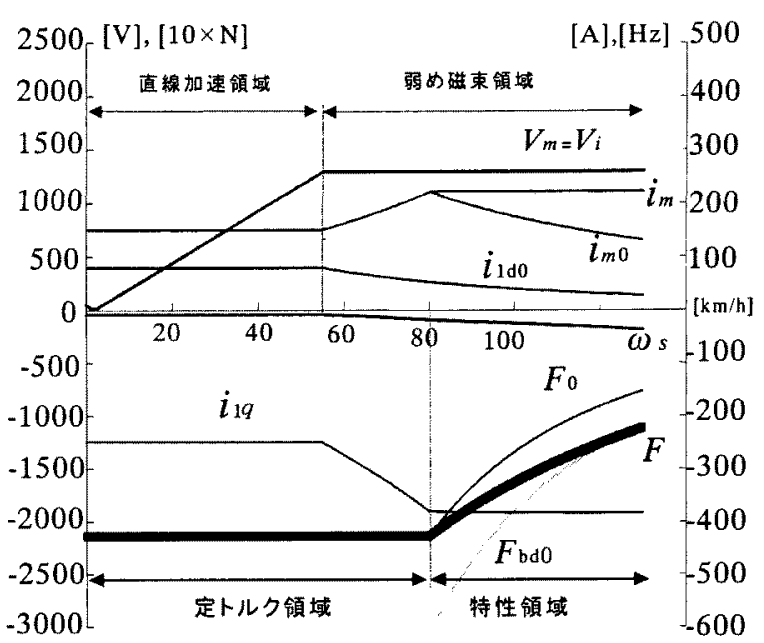

図 5 回生ブレーキ性能曲線 $(R=0[\Omega]$, 高速域電流増加)

Fig.5 Characteristic curves of regenerative brake.

$(R=0[\Omega]$, increasing current in the high speed range.)

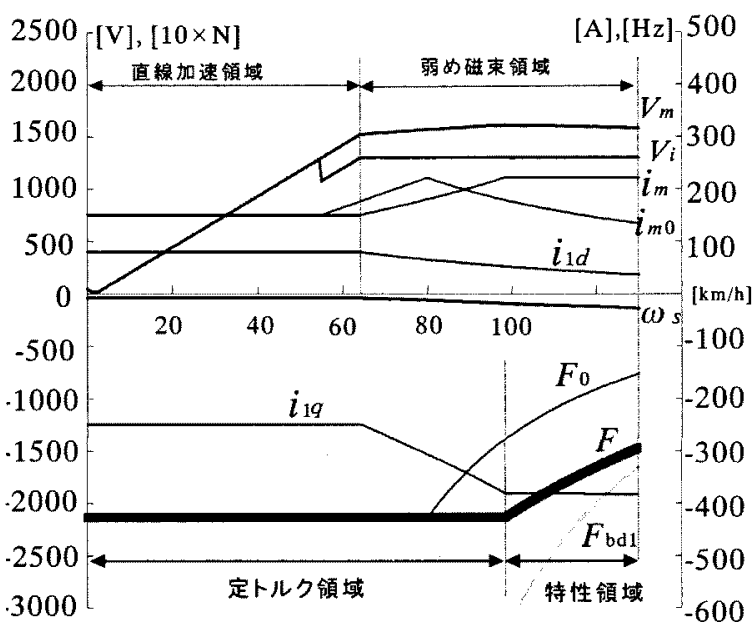

図 7 回生ブレーキ性能曲線 $(R=1[\Omega])$

Fig.7 Characteristic curves of regenerating brake. $(R=1[\Omega])$

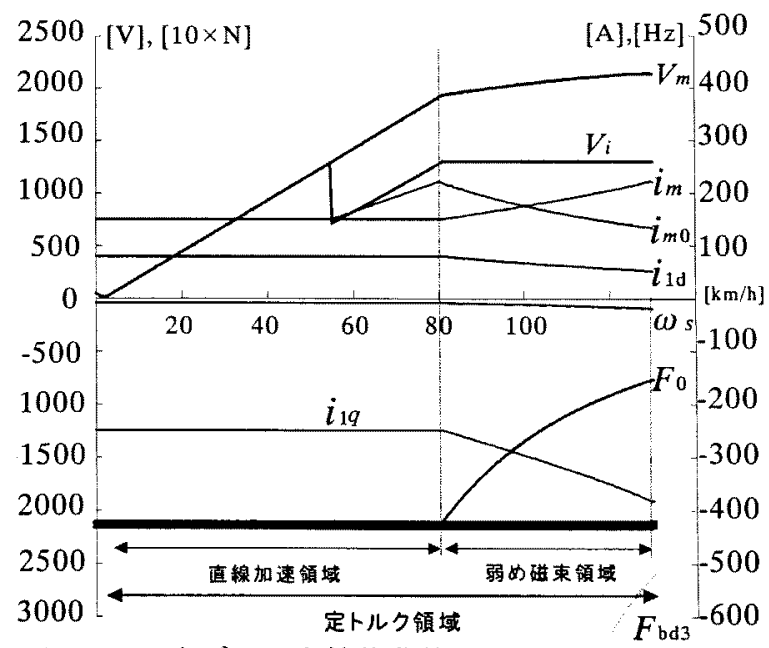

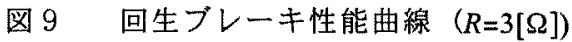

Fig. 9 Characteristic curves of regenerating brake.

$(R=3[\Omega])$ 
に強められていく。速度 $55[\mathrm{~km} / \mathrm{h}]$ まで減速すると磁束 は最大值をとる。速度 $80[\mathrm{~km} / \mathrm{h}]$ から速度 $55[\mathrm{~km} / \mathrm{h}]$ の領 域は, 弱め磁束領域である。図 4 では弱め磁束領域に おいて定トルクとなるように電流を与えている。

速度 $55[\mathrm{~km} / \mathrm{h}]$ 以下では, 端子電圧 $V_{m}$ は一次角周波 数 $\omega 1$ に比例し磁束は一定に制御される。本論文では, 端子電圧 $V_{m}$ が一次角周波数 $\omega 1$ に比例する領域を值線 加速領域と呼ぶ。

現在の一般的なブレ一キ方式では, 運転士の扱う， ッチに応じて要求される減速度から編成全体のブレー キ力を演算し，電気ブレーキ力を優先的に用いる。そ して, 電気ブレ一キカのみでは不足する編成ブレーキ 力を機械ブレ一キカで補う仕組みとなっている。例え ば, 電動車 3 両と付随車 5 両の 8 両編成車両の場合を 考える (以降, 電動車を $\mathrm{M}$ 車, 付随車を $\mathrm{T}$ 車と呼ぶこ とにする。この場合は $3 \mathrm{M} 5 \mathrm{~T}$ 編成車両となる)。要求さ れる減速度を, $3 \mathrm{M}$ 車の電気ブレーキのみで満たすこ とができないと, 編成ブレーキカと電気ブレーキカと の差を機械ブレーキが負担することになる。そのため， 速度 $80[\mathrm{~km} / \mathrm{h}]$ 以上の高速域においては, 編成ブレーキ カの大部分を機械ブレーキが受け持つ。

<3． 2> 高速域において電流を増大させた回生性 能曲線図 5 は高速域において電流ピーク值を維持 したままの状態にしたときの電気ブレーキカ $F_{0}$ とそ の時の各特性を示した。停動卜ルクを超えない䇭囲で, 主電動機の高速域の出力及び熱的容量を增加させた場 合に相当する。

\section{$\langle 3 ， 3>$ 高速域において発電抵抗を㨉入した回生} 性能曲楾图 6 は, 速度 $55[\mathrm{~km} / \mathrm{h}]$ より高速域に打い て, 発電抵抗值 $\mathrm{Rs}=1,2,3[\Omega]$ を挿入した時の停動トルク 特性を示す。Fbd は停動トルクてbdをブレーキカに換算 した值である。添字の bd0 は抵抗を㨂入しない場合で あり，bd $1, b d 2, b d 3$ 㤝発電抵抗 $R s=1,2,3[\Omega]$ を㨂入 した場合である。

図 7 は高速域において発電抵抗 $R=1[\Omega]$ を挿入した ときの回生性能曲線を示す。速度 $130[\mathrm{~km} / \mathrm{h}]$ 加ら減速し， 速度 $98[\mathrm{~km} / \mathrm{h}]$ で定トルク領域（弱め磁束）のブレーキ 力(このとき $F=-2136[10 \times \mathrm{N}])$ に達する。その際, 定卜 ルクの值に達するまで電流実効值 Im はピーク值 （222[A]）をとることとする。また，インバータ交流 出力端子電圧 $V i$ 惊, 直流架線電圧の制限約 $1700[\mathrm{~V}]$ に 対応する交流 $1300[\mathrm{~V}]$ の值を上限とする。回生ブレー キ時は, 発電抵抗による電圧降下分だけ主電動機端子 電圧をインバー夕端子電圧上限（1300[V]）より上昇さ せることができる。従って，停動トルクは端子電圧の 2 乗に比例することから, 高速域（定電圧領域）にお いて電気ブレ一キカが增大する。主電動機端子電压 $V m$ は最大 $1600[\mathrm{~V}]$ であった。但し, 低速域では各ノッチ によって設定される一定のトルクをとるため，抵抗挿
入によりトルクを增大させる必要がない。そのため, 架線への回生効膟低下を防ぐ目的で, 直線加速終端 $(55[\mathrm{~km} / \mathrm{h}])$ において発電抵抗を短絡させている。この ような回生ブレ一キカ特性を与えると, 速度 $64[\mathrm{~km} / \mathrm{h}]$ において直線加速領域の限流值（定トルク域における 電流值）と等しくなり, 速度 $64[\mathrm{~km} / \mathrm{h}]$ 以下では直線加 速領域となる。速度 $55[\mathrm{~km} / \mathrm{h}]$ まで減速すると, 主電動 機端子電圧は $1300[\mathrm{~V}]$ となる。この制御方式によると， 直線加速領域は $0 \sim 55[\mathrm{~km} / \mathrm{h}]$ から $0 \sim 64[\mathrm{~km} / \mathrm{h}]$ まで抝大 し，定トルク領域は $98[\mathrm{~km} / \mathrm{h}]$ まで㹡大できた。

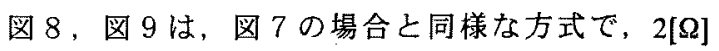
と $3[\Omega]$ の発電抵抗を㨉入した場合の回生性能曲線を

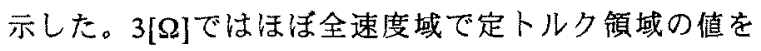
とることが可能である。主電動機の最大端子電圧 $V_{m}$ はそれぞれ 1900[V]と2150[V]となった。

表 2 制御領域

Table. 2 Control range

\begin{tabular}{|c|c|c|}
\hline 抵抗值 & $\begin{array}{r}\text { 定トルク域 } \\
{[\mathrm{km} / \mathrm{h}]}\end{array}$ & $\begin{array}{r}\text { 特性領域 } \\
{[\mathrm{km} / \mathrm{h}]}\end{array}$ \\
\hline$R=0[\Omega]$ & $0 \sim 80$ & $80 \sim 130$ \\
\hline$R=1[\Omega]$ & $0 \sim 98$ & $98 \sim 130$ \\
\hline$R=2[\Omega]$ & $0 \sim 115$ & $115 \sim 130$ \\
\hline$R=3[\Omega]$ & $0 \sim 129$ & $129 \sim 130$ \\
\hline
\end{tabular}

以上の検討から，回生ブレーキ時に発電抵抗を㨂入 することで, 高速域において電気ブレーキ力を增大で きることが示された。

\section{4. 電気ブレーキ性能評価}

本節では，表 3 に示した 3 MST 編成電車をモデルと して, 前節で示した回生ブレーキ性能曲線を用いて走 行した時の RMS 電流 ${ }^{(8)}$ とブレ一キ時における運動工 ネルギー処理について検討する。

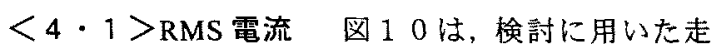
行曲線を示している。駅間は $5[\mathrm{~km}]$ である。停止状態 から最大加速度で $130[\mathrm{~km} / \mathrm{h}]$ まで加速を行い, 惰行, 减 速（減速度 $3[\mathrm{~km} / \mathrm{h} / \mathrm{s}] ） 乙$ 停止に至っている（現在の一 般的な運行ダイヤでは, 減速度 $2 \sim 3[\mathrm{~km} / \mathrm{h} / \mathrm{s}]$ の範团で 減速している)。

このような走行パターンにおいて, 図 4〜9に示し た回生性能曲線の特性を用いて減速させる之, 主電動 機の実効值電流 $I m$ の特性が高速域でそれぞれ異なる。 主電動機の銅損による温度上昇は, 絶縁材料の寿命に 大きな影響を与える。そのため, 各走行計算每に, 銅 損による温度上昇に対応する，走行開始時点からの RMS 電流 Irms を(12)式より求めた(8)。

$$
I_{r m s}=\sqrt{\frac{1}{T} \int_{0}^{T} I_{m}^{2} d t}
$$

ここで, $t:$ 時間, $T:$ 走行に要した時間 
表 4 は, 図 4 から図 9 の回生ブレ一キ特性を用いて 図10の走行曲線に沿って走行した時の RMS 電流を 示す。

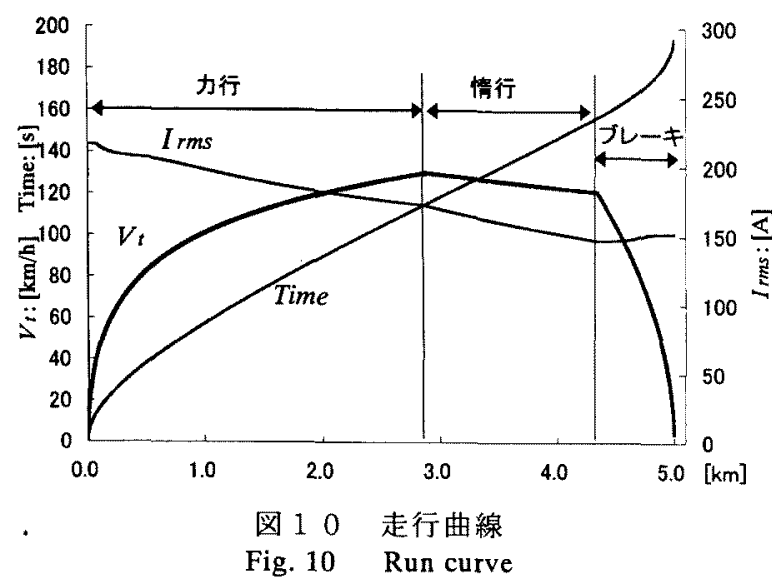

現行（図 4）に対し，高速域で電流を增大させる場 合（図 5) と発電抵抗 $1[\Omega]$ 挿入時（図 7) の場合は, RMS 電流が增加した。また, $2[\Omega], 3[\Omega]$ の発電抵抗を 挿入した場合（図 8，図9）では，現行よりも減少し た。走行曲線における力行時の特性はどの場合でも同 じであり，ブレーキ時の減速度は一定である。今回検 討に用いた回生性能曲線では，弱め磁束領域で定トル ク運転を行う速度域において，すべり周波数の調節に よりトルク電流を增加させている。発電抵抗挿入によ り直線加速終端が高速側に拡大されると, 弱磁束領 域において電流実効值 $I m$ が現行に比べ減少する。発電 抵抗の值を増加させれば，より高速側まで定トルク領 域が拡大し，RMS 電流が減少する。

表 33 M5T 編成車両の構成 Table.3 Structure of train set (3M5T)

\begin{tabular}{|c|c|}
\hline $\begin{array}{c}\text { 電動車 } 3 \text { 両 }(3 \mathrm{M}) \\
(\text { 運転台付車両 } 1 \text { 両を含む) }\end{array}$ & $115,900[\mathrm{~kg}]$ \\
\hline \begin{tabular}{c} 
(運転台付車両 1 両を含む) \\
\hline 荷重（満車）
\end{tabular} & $148,400[\mathrm{~kg}]$ \\
\hline $\begin{array}{c}\text { 編成ブレーキ力 } \\
(\text { 減速度 }-3.0[\mathrm{~km} / \mathrm{h} / \mathrm{s}])\end{array}$ & $17,000[\mathrm{~kg}] /$ 両 \\
\hline 電動車 $(1 \mathrm{M})$ あたりの主電動機数 & $33,359[10 \times \mathrm{N}]$ \\
\hline $\begin{array}{c}\text { 編成電気ブレーキ力 }(3 \mathrm{M}) \\
\text { (定トルク域) }\end{array}$ & $25,636[10 \times \mathrm{N}]$ \\
\hline
\end{tabular}

表 4 RMS 電流

Table. 4 RMS current

\begin{tabular}{|c:c|c|c|c|}
\hline 現行 & $\begin{array}{c}\text { 電流增大 } \\
\text { (高速域) }\end{array}$ & $R=1[\Omega]$ & $R=2[\Omega]$ & $R=3[\Omega]$ \\
\hline $148.6[\mathrm{~A}]$ & $152.7[\mathrm{~A}]$ & $150.6[\mathrm{~A}]$ & $148.7[\mathrm{~A}]$ & $147.1[\mathrm{~A}]$ \\
\hline $100.0(\%)$ & $102.8(\%)$ & $101.3(\%)$ & $100.1(\%)$ & $99.0(\%)$ \\
\hline
\end{tabular}

<4.2>エネルギーと電力 本節では, ブレーキ エネルギー処理の内訳とピーク電力について検討して
いる。

（1）ブレーキエネルギー分担率最高速度 $130[\mathrm{~km} / \mathrm{h}]$ から停止まで減速度 $3[\mathrm{~km} / \mathrm{h} / \mathrm{s}]$ で減速するた めに，表 3 に示す編成ブレーキ力 $(33,359[10 \times \mathrm{N}])$ を 与えた。このとき，電気ブレーキと機械ブレーキが編 成車両の運動エネルギーを吸収する。そこで, 電気ブ レーキと機械ブレーキが吸収するエネルギーの分担比 と, 主電動機の吸収電力及び架線への回生電力を調心゙ た。

電気ブレーキ分担率と回生ブレーキ分担率につい て以下に定義する。

$$
\begin{aligned}
& \text { 電気ブレーキ分担率 } \\
& \qquad=\frac{\text { 主電動機発電エネルギ一 }}{\text { 編成車両運動エネルギー }} \times 100[\%]
\end{aligned}
$$

回生ブレーキ分担率

$$
=\frac{\text { 架線に戻るエネルギー }}{\text { 編成車両運動エネルギー }} \times 100[\%]
$$

図 11 は, 現行の回生ブレーキ力特性を用いて編成 車両を $130[\mathrm{~km} / \mathrm{h}]$ から減速度 $3[\mathrm{~km} / \mathrm{h} / \mathrm{s}]$ で減速させたと きの回生電力量を示している。

ここで,

$V t[\mathrm{~km} / \mathrm{h}]:$ 編成車両の速度,

$E \nu[\mathrm{kWh}]$ : 編成車両の蓮動エネルギー

$E_{m}[\mathrm{kWh}]$ : 編成車両の主電動機発電エネルギー $E_{r}[\mathrm{kWh}]:$ 架線への回生エネルギー

$E_{v}-E_{m}[\mathrm{kWh}]$ : 機械ブレーキで受け持つエネルギー $E_{m}-E_{r}[\mathrm{kWh}]$ : 発電抵抗で受け持つエネルギー $P_{v}[\mathrm{~kW}]$ : 編成車雨のパワー

$P_{m}[\mathrm{~kW}] ：$ 主電動機のパワー

$\operatorname{Pr}[\mathrm{kW}]$ : 架線への回生パワー

$P_{v}-P_{m}[\mathrm{~kW}]$ : 機械ブレーキで受け持つパワー

$P_{m}-\operatorname{Pr}[\mathrm{kW}]$ : 発電抵抗で受け持つパワー

図12 は図 5 の回生性能曲線をもとに, 発電抵抗を 用いないで，高速域においてピーク電流実効值 （222[A]）を越えないようにブレーキ力を增大させた 場合の各電力及び電力量を表している。高速域でトル クを增大させているため，現行よりも電気ブレーキ分 担率及び回生ブレーキ分担率は 5.2[\%]増加した。

発電抵抗を挿入した場合を図 $13 ， 14 ， 15$ に示 す。Prは架線へ返る電力を表す。主電動機が発電する パワーP $P_{m}$ とPr との差が発電抵抗により消費されるパ ワーとなる。

図 16 は $130[\mathrm{~km} / \mathrm{h}]$ から $80[\mathrm{~km} / \mathrm{h}]$ まで, 図 17 は $130[\mathrm{~km} / \mathrm{h}]$ から $0[\mathrm{~km} / \mathrm{h}]$ までのブレーキ時（堿速度 $3[\mathrm{~km} / \mathrm{h}]$ ) における編成車両の運動エネルギ一処理の内 訳を示す。図中の各棒グラフの無色部分が機械ブレー キが吸収するエネルギーであり，その他は，主電動機 


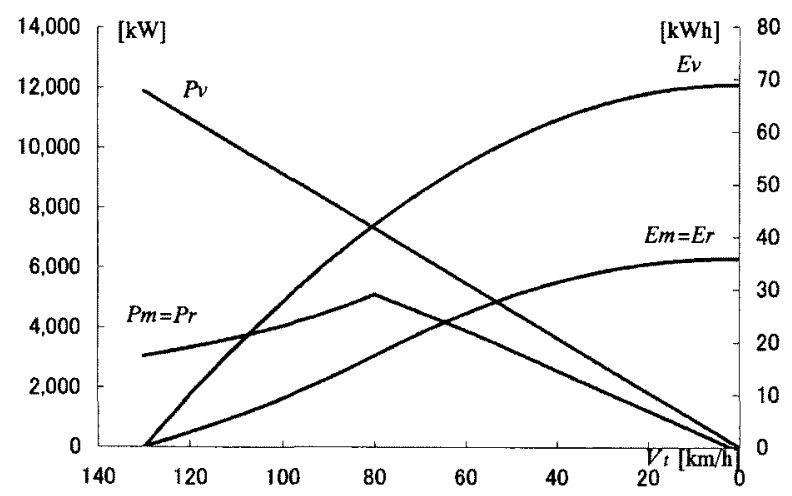

図 11 回生電力及び電力量線図 (現行)

Fig. 11 Regenerative power and electric energy.

(conventional)

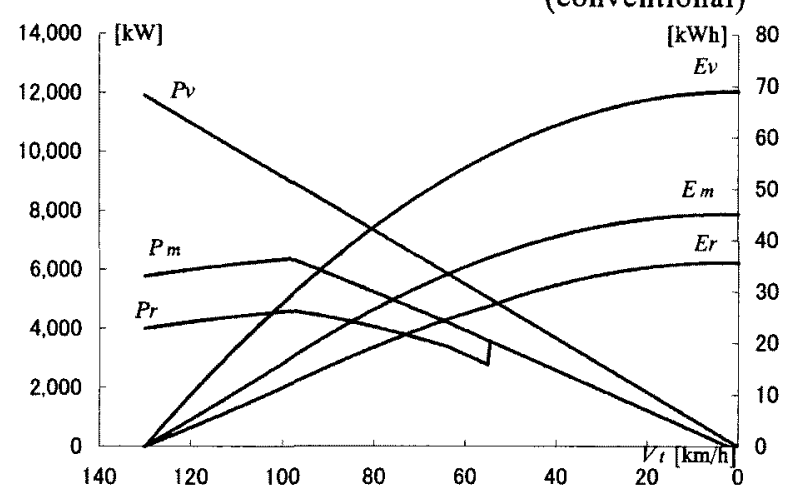

図1 3 回生電力及び電力量線図 $(\mathbf{R}=1[\Omega])$

Fig. 13 Regenerative power and electric energy. $(R=1[\Omega])$

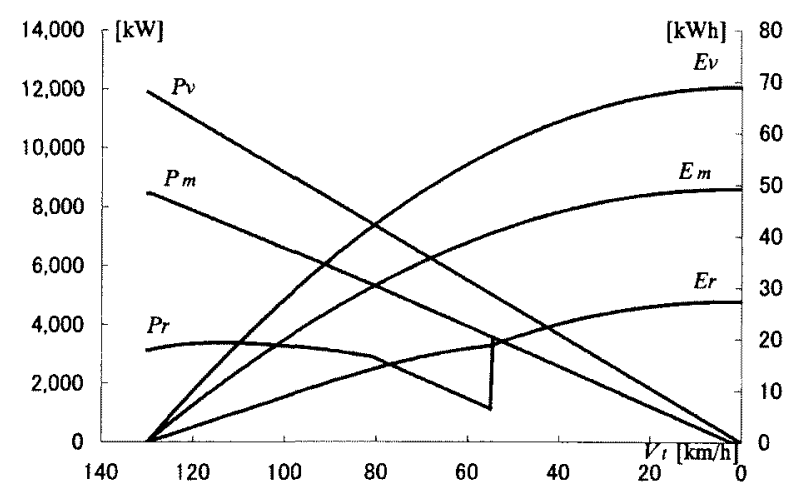

図 15 回生電力及び電力量線図 $(\mathrm{R}=3[\Omega]))$

Fig. 15 Regenerative power and electric nergy. $(R=3[\Omega])$

が吸収したエネルギー（発電抵抗で消費されるエネル ギーと架線へ返るエネルギー）である。

編成車両の速度 $130[\mathrm{~km} / \mathrm{h}]$ から $80[\mathrm{~km} / \mathrm{h}]$ まで減速す るときの運動エネルギーは 42.4[kWh]である。図 17 から速度 $130[\mathrm{~km} / \mathrm{h}]$ において, 編成車両の全運動エネル ギーは $68.9[\mathrm{kWh}]$ となるため, 130[km/h]から $80[\mathrm{~km} / \mathrm{h}]$

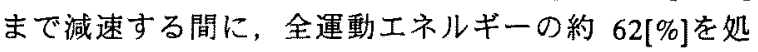
理しなければならないことになる。

図 16 には, $5 \mathrm{M} 3 \mathrm{~T}$ と $6 \mathrm{M} 2 \mathrm{~T}$ 編成車両に, 現行の回 生性能曲線を用いて $130[\mathrm{~km} / \mathrm{h}]$ から $80[\mathrm{~km} / \mathrm{h}]$ まで減速

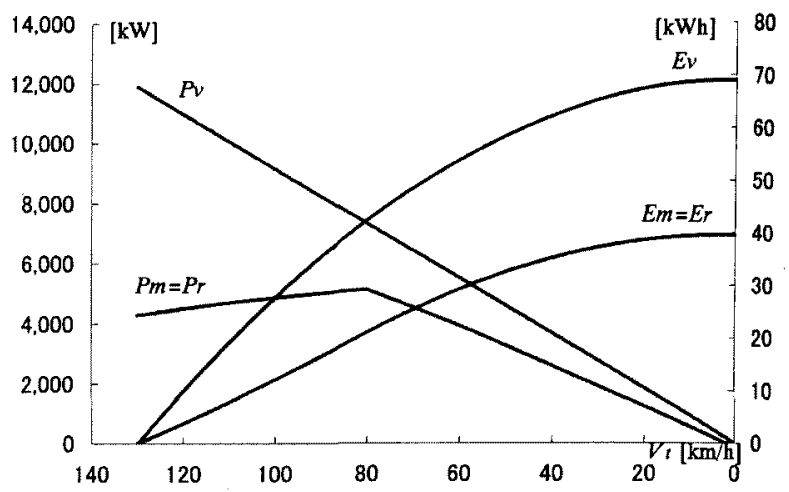

図 12 回生電力及び電力量線図（高速域電流增大）

Fig. 12 Regenerative power and electric energy.

( $R=0[\Omega]$, current increased in the high speed range.)

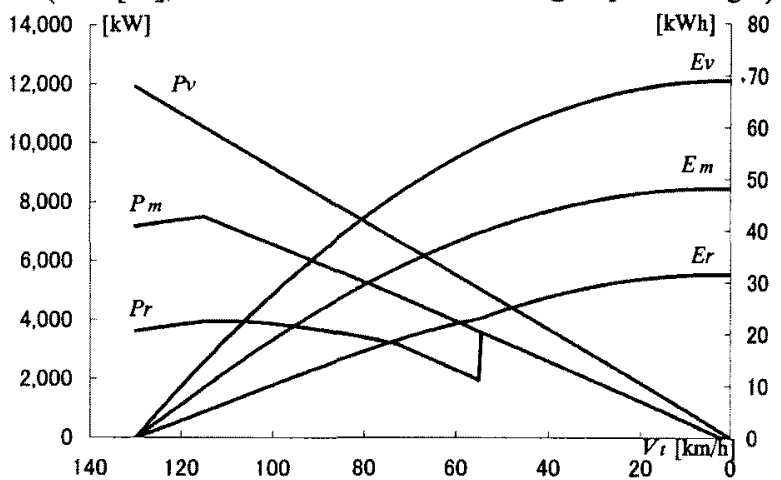

図 144 回生電力及び電力量線図 $(\mathrm{R}=2[\Omega])$

Fig. 14 Regenerative power and electric energy. $(\mathrm{R}=2[\Omega])$

（減速度 $3[\mathrm{~km} / \mathrm{h} / \mathrm{s}] ）$ する間の電気ブレーキエネルギー も合わせて示してある。電気プレーキで処理したエネ ルギーが発電抵抗 $3[\Omega]$ 挿入時には $30.5[\mathrm{kWh}]$ であり， 5M3T では 28.1[kWh], 6M2T では $32.0[\mathrm{kWh}]$ あった。 言い換えると，発電抵抗 $3[\Omega]$ 抙入時には $5.5 \mathrm{M} 2.5 \mathrm{~T}$ 編 成相当の電気プレーキエネルギー処理能力があると考 えることができる。

（2）ピーク電力 表 5 は, 架線への回生ピーク電 力を表している。発電抵抗值が大きくなるにつれ, 回 生ピーク電力が小さくなる。発電抵抗 3[S]の場合では, 現行に対して約 70[\%]よなった。

表 5 架線への回生ピーク電力

Table. 5 Peak regenerative power to trolly wire.

\begin{tabular}{|c|c|c|c|}
\hline 現行 & $R=1[\Omega]$ & $R=2[\Omega]$ & $R=3[\Omega]$ \\
\hline $5,102[\mathrm{~kW}]$ & $4,582[\mathrm{~kW}]$ & $3,941[\mathrm{~kW}]$ & $3,551[\mathrm{~kW}]$ \\
\hline $100.0[\%]$ & $89.8[\%]$ & $77.2[\%]$ & $69.6[\%]$ \\
\hline
\end{tabular}

表 6 主電動機の発電ピーク電力

Table. 6 Peak regenerative power of main motor.

\begin{tabular}{|c|c|c|c|}
\hline 現行 & $R=1[\Omega]$ & $R=2[\Omega]$ & $R=3[\Omega]$ \\
\hline $5,102[\mathrm{~kW}]$ & $6,358[\mathrm{~kW}]$ & $7,475[\mathrm{~kW}]$ & $8,450[\mathrm{~kW}]$ \\
\hline $100.0[\%]$ & $124.6[\%]$ & $146.5[\%]$ & $165.6[\%]$ \\
\hline
\end{tabular}




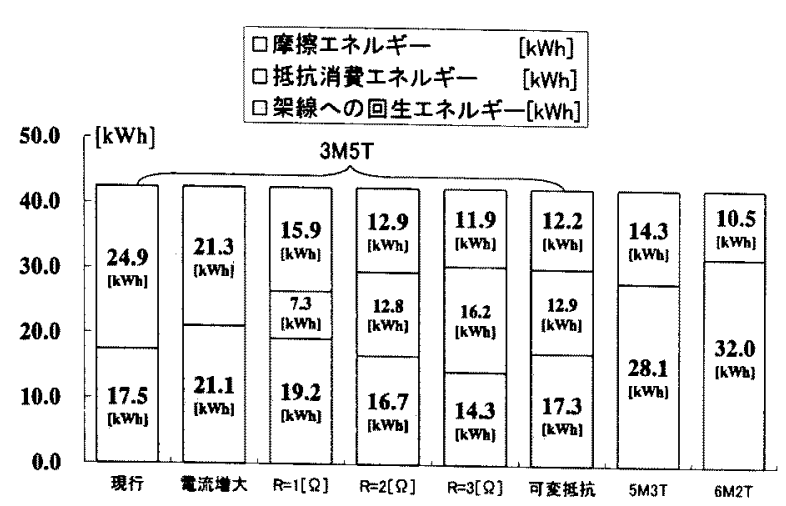

図 16 プレーキエネルギーの内訳 $(130 \rightarrow 80[\mathrm{~km} / \mathrm{h}])$

Fig. 16 Details of braking energy of train set.

同一き電区間において回生電力を消費する負荷車 両が少ないと, 回生失効（回生電力を返すことができ ず電気ブレーキが絞られ，機械ブレーキが立ち上がる 場合）が少なからず生ずる。発電抵抗を挿入した電気 ブレーキ方式は, 軽負荷となりやすい線区に対し, 回 生失効を低減させることが期待できる。

主電動機の発電ピーク電力を表 6 に示す。発電抵抗 $3[\Omega]$ 挿入時の主電動機発電ピーク電力は, 現行に対し $165.6[\%]$ となる。

$<4 \cdot 3>$ 回生電力量と発電抵抗值の設定発電抵 抗の最適值は，走行する線区により異なる。

例えば，高密度輸送線区（山手線や中央線など）の 場合, 絶えず負荷となる車両が存在するため, 省エネ ルギーの锶点から架線への回生電力量は減らさないこ とが求められる。そのため, 発電抵抗の值はあまり大 きくない方が望ましい。これに対して, 負荷となる車 両が少ない閑散線区に対しては,できるだけ電気ブレ 一キを生かすために，発電抵抗の値を大きめに設定す ることが望ましい。(上記はほんの一例であり，車両や 線区によって要求される性能が変わる。)

発電抵抗を車両速度に応じて切り替えることが可能 であれば，架線への回生電力量を現行とほほ同じにす

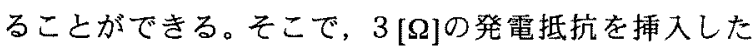
時と同じ電気ブレーキ力（ほぼ全速度域が定トルク） が得られるように, 発電抵抗值を列車速度に応じて 3 $\rightarrow 2 \rightarrow 1[\Omega]$ と切り替えた場合の運動エネルギー処理の 内訳を図 16 に可変抵抗と注記して示す。

また, 開閉器と発電抵抗を搭載する際のスペースと 重量の増加に関しては, 抵抗制御電車の抵抗器の容量 及び重量を参考にすると，スペース的にはさほど問題 なく, $1 \mathrm{M}$ 当たり 1 トン程度の重量增である。 $3 \mathrm{M} 5$ 下編成車両の荷重を含めた全重量は約400トンであ る。3M 車両分で 3 トン程度の重量增となるため, 編 成重量に対する增加割合は $1 \%$ 程度となる。従って, 編成全体に対する重量增加は軽微であり, 力行時の工 ネルギー消費への影響は比較的少ない。

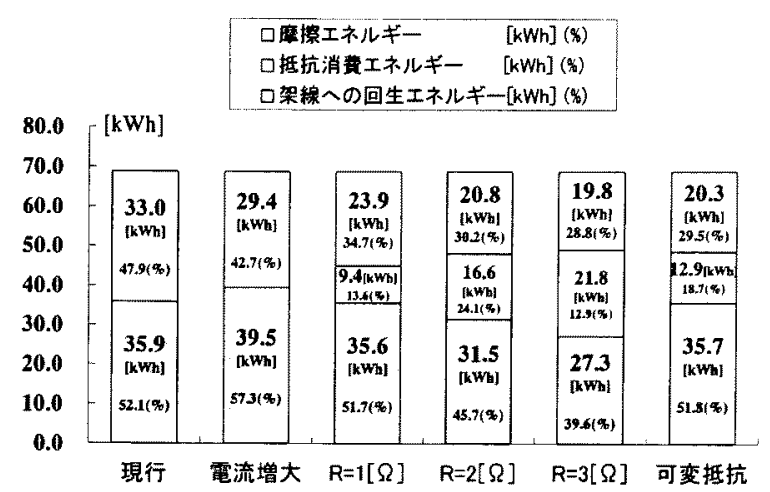

図 17 ブレーキエネルギーの内訳 $(130[\mathrm{~km} / \mathrm{h}] \rightarrow 0[\mathrm{~km} / \mathrm{h}])$ Fig. 17 Details of braking energy of train set(3M5T)

$<4 \cdot 4>$ 主電動機の耐電压抵抗挿入時には主電 動機の端子電圧が通常回生時よりも上昇するため，主 電動機の耐圧を考慮しなくてはならない。JIS E 6102 鉄道車画用一交流電動機一試験方法によれば, $2.25 \mathrm{E}+2,000[\mathrm{~V}] \fallingdotseq 5,400[\mathrm{~V}]$ を印加する耐電圧試験を行 っている。(ここで $\mathrm{E}$ は架線電压 1,500[V])

架線電圧の変動範囲は, $900 \mathrm{~V} \sim 1,900[\mathrm{~V}]$ ありり,こ の最大值に対応する交流電压は1,482[V]である。架線

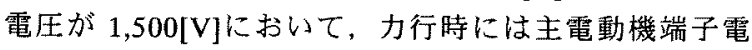
圧には約 $1170[\mathrm{~V}]$ 実効值電圧が加わる。

力行中においても, 主電動機に加わる電圧が, 定格 の約 1.26 倍にまで上昇する。1 $[\Omega]$ の発電抵抗挿入 時には, 最大 1.36 倍 (主電動機の実効值電圧 $1,600[\mathrm{~V}]$ ) である。このため，電圧上昇分の影響には，検討が必 要と考えるが，これまでの鉄道車両における主電動機 の使い方（例えば，旧国鉄 103 系電車では，定格 375[V] の直流電動機を, 発電ブレーキ時には最大 800[V]で使

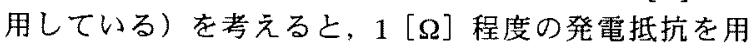
いる場合では，既存の主電動機をそのまま使用できる 可能性がある。発電抵抗が $3[\Omega] の$ 場合は, 主電動機の 最大端子電圧は $2,150[\mathrm{~V}]$ となり, 現行に対して 1.65 倍 の電圧となる。既存の主電動機を用いる場合, サージ 電圧などによる絶縁への影響を考虑する必要があるか もしれない。

\section{5.おわりに}

インバータや主電動機の電圧・電流の制約により高 速域における電気ブレーキ力が小さい場合, 高速域か らのブレーキは，現状では機械ブレーキに大きく頼ら ざるを得ない。高速域では, 編成本両の運動エネルギ 一が大きいため，機械ブレーキに大きな負担が掛かる。

本論文では，機械ブレーキのメンテナンス軽減に奇 与する, 発電抵抗を用いた高速域における電気ブレ一 キ力增大の検討を行った。その結果を以下に要約する。

(1)発電抵抗を用いることで, インバータ容量を增 やさずに，高速域の電気ブレーキ力を增大する方法を 
提示した。

(2)機械プレーキの負担減により, 制輪子の交換周 期や車輪削正の周期の延長が見込まれる。

(3)本論文で検討した $3 \mathrm{M} 5 \mathrm{~T}$ 編成電車において 3[S] の発電抵抗挿入した場合では, 高速域 $(130 \rightarrow 80[\mathrm{~km} / \mathrm{h}])$ において 5.5 M2.5T 相当の電気ブレーキ能力（減速度 $3[\mathrm{~km} / \mathrm{h} / \mathrm{s}]$ ) がある。

(4)同一き電区間において, 力行車が少ない軽負荷 時の回生失効を抑制することができる。

(5)主電動機の耐電圧次第では, 既存のモータに即 適応できる可能性が高い。

今回は, 直流き電区間を走行する近郊電車をモデル に検討したが，交流き電区間を走行するインバータ車 の場合でも, 電気ブレーキ力の増大は同様と考えてい る。今後は, 主電動機の抵抗短絡時の制御安定性につ いて検討を行う予定である。

(平成 12 年 3 月 2 日受付, 同 12 年 8 月 9 日再受付)

\section{考文献}

（1）曽根, 芦屋：「電車の純電気ブレーキ化」第 34 回 鉄道サイバネ, 513, pp.194/197, 1997

(2) 小笠, 永井, 渡邊, 戸田:「零速までの電気ブレ一 キ試験台試験」電学論 Vol.119D, No.3, March, 1999

(3) 渡邊, 小笠; 「停止まで使える電気ブレーキ」RRR, 56 巻 2 号,p10/15,1999

(4) 佐藤, 宮路 :「純電気ブレーキの使用実績について」 第 36 回鉄道サイバネ, 515,p194/197, 1999

(5) 渡邊：「鉄損を考虑した誘導機の定常特性解析」回 転機研究会資料, RM-00-5, 2000

(6) 中沢, 戸田, 安岡 : 「電圧固定モードでの誘導電動 機ベクトル制御」電学論 D, 118 巻 9 号, 平成 10 年

(7) 土谷, 江上 : 現代制御工学 (産業図書)

(8) 川添: 交流電気車両要論 (電気車研究会) 1971

(9) 山下, 小笠, 渡邊 :「高速域における電気ブレーキ 䇩囲拡大の検討」平成 11 年電気学会産業応用 I -121 p $387 / 388$

山下 道寛

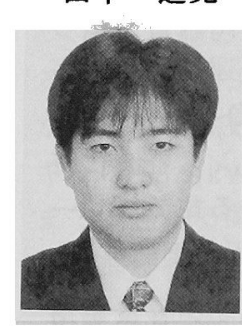

（正員）昭和 46 年 1 月 29 日生。平 成 5 年北見工業大学電気工学科卒業。 平成 10 年 3 月北海道大学工学研究科 システム情報工学専攻博士課程修了。 同年 4 月，（財) 鉄道総合技術研究所入 社。現在, 同車両制御技術研究部駆動 制グループ研究員。誘導電動機制御, 粘着制御の研究開発に従事。計測自動 制御学会会員。博士 (工学)

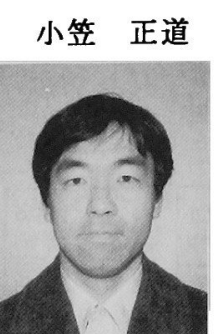

渡遥 朝紀

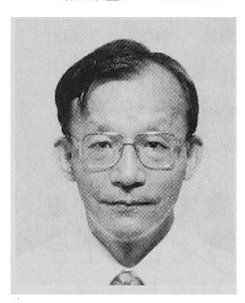

(正員) 昭和 41 年 5 月 31 日生。平成 2 年 3 月東京大学工学部電気工学科卒業。 同年 4 月（財）鉄道総合技術研究所入社。 現在, 同車両制御技術研究部駆動制御グ ループ副主任研究員。電気鉄道車両の性 能, 電力変換技術の研究開発に従事。計 測自動制御学会会員。

（正員）昭和 24 年 4 月 9 日生。昭和 4 7 年 4 月東京大学工学部電気工学科卒業。 同年 5 月国鉄入社。現在，(財) 鉄道総合 技術研究所車両制御技術研究部制御グル 一プ主管研究員。電気鉄道車両の性能, 粘着制御, 列車制御, 電力変換制御の研 究開発に従事。計測自動制御学会会員。 I E E E 会員。 